\title{
A Valid Warning or Clinical Lore: an Evaluation of Safety Outcomes of Remdesivir in Patients with Impaired Renal Function from a Multicenter Matched Cohort
}

\author{
Tyler W. Ackley,a Dayna McManus, ${ }^{a}$ Jeffrey E. Topal, a,b Brian Cicali,c (D) Sunish Shah ${ }^{a, d}$ \\ aDepartment of Pharmacy, Yale New Haven Health System, New Haven, Connecticut, USA \\ bYale University School of Medicine, Department of Internal Medicine, Section of Infectious Diseases, New Haven, Connecticut, USA \\ 'Center for Pharmacometrics and Systems Pharmacology, Department of Pharmaceutics, University of Florida College of Pharmacy, Orlando, Florida, USA \\ dDepartment of Pharmacy, University of Pittsburgh Medical Center, Pittsburgh, Pennsylvania, USA
}

\begin{abstract}
Per prescribing guidance, remdesivir is not recommended for SARSCoV-2 in patients with renal disease given the absence of safety data in this patient population. This study was a multicenter, retrospective chart review of hospitalized patients with SARS-CoV-2 who received remdesivir. Safety outcomes were compared between patients with an estimated creatinine clearance $(\mathrm{eCrCl})$ of $<30 \mathrm{ml} / \mathrm{min}$ and an $\mathrm{eCrCl}$ of $\geq 30 \mathrm{ml} / \mathrm{min}$. The primary endpoint was acute kidney injury (AKI) at the end of treatment (EOT). Of 359 patients who received remdesivir, 347 met inclusion criteria. Patients with an $\mathrm{eCrCl}$ of $<30 \mathrm{ml} / \mathrm{min}$ were older \{median, 80 years (interquartile range [IQR], 63.8 to 89 ) versus 62 (IQR, 54 to 74 ); $P<0.001\}$, were more likely to be on vasopressors on the day of remdesivir administration (30\% versus $12.7 \%$; $P=0.003$ ), and were more likely to be mechanically ventilated during remdesivir therapy $(27.5 \%$ versus $12.4 \% ; P=0.01)$ than those with an $\mathrm{eCrCl}$ of $\geq 30 \mathrm{ml} / \mathrm{min}$. Despite these confounders, there was no significant difference in the frequency of EOT AKI (5\% versus $2.3 \% ; P=0.283$ ) or early discontinuation due to abnormal liver function tests (LFTs) $(0 \%$ versus 3.9\%; $P=0.374)$. Of the $5 \%$ of patients who developed EOT AKI on remdesivir with an $\mathrm{eCrCl}<30 \mathrm{ml} / \mathrm{min}$, no cases were attributable to remdesivir administration per the treating physician. Comparable safety outcomes were observed when 1:1 nearest neighbor matching was applied to account for baseline confounders. In conclusion, remdesivir administration was not significantly associated with increased EOT AKI in patients with an $\mathrm{eCrCl}$ of $<30 \mathrm{ml} / \mathrm{min}$ compared to patients with an $\mathrm{eCrCl}$ of $\geq 30 \mathrm{ml} / \mathrm{min}$.
\end{abstract}

KEYWORDS COVID, SARS-CoV-2, SBECD, chronic kidney disease, remdesivir, renal failure

- he novel coronavirus 2019 (SARS-CoV-2) has been recognized as a human pathogen associated with potentially severe respiratory infections. Since its identification in December 2019, the virus has led to nearly 45 million infections and over 1.3 million deaths worldwide (https://coronavirus.jhu.edu/map.html). Of those infected, approximately $15 \%$ of patients will develop severe pneumonia, and $5 \%$ will develop respiratory or multiorgan failure (1). Given the high morbidity and mortality associated with this disease, the development of an effective and safe treatment is a public health priority.

Remdesivir is a nucleotide analog with in vitro activity against multiple coronaviruses, including SARS-CoV, MERS-CoV, and, more recently, SARS-CoV-2 through inhibition of viral RNA-dependent RNA polymerase (2). More importantly, a randomized trial found that remdesivir was superior to placebo in shortening the time to recovery in
Citation Ackley TW, McManus D, Topal JE, Cicali B, Shah S. 2021. A valid warning or clinical lore: an evaluation of safety outcomes of remdesivir in patients with impaired renal function from a multicenter matched cohort. Antimicrob Agents Chemother 65:e02290-20. https://doi.org/10.1128/AAC.02290-20. Copyright $\odot 2021$ American Society for Microbiology. All Rights Reserved. Address correspondence to Sunish Shah, Sunishshah93@gmail.com.

Received 28 October 2020

Returned for modification 11 November 2020

Accepted 19 November 2020

Accepted manuscript posted online 23

November 2020

Published 20 January 2021 
patients with SARS-CoV-2 (3). Combined data from an observational study and randomized trial have even demonstrated a mortality benefit compared to standard care in the treatment of SARS-CoV-2 (4). However, available data are conflicting, and the findings of an early clinical trial failed to show that remdesivir was associated with any statistically significant clinical benefits compared to placebo in patients with SARSCoV-2 (5). Nevertheless, given the severity of the SARS-CoV-2 pandemic and the limited armamentarium of available treatment options, remdesivir has been granted approval by the Food and Drug Administration (FDA) for the treatment of patients hospitalized with SARS-CoV-2 (2).

Although there is a paucity of data evaluating remdesivir's pharmacokinetic parameters, a study in healthy volunteers without SARS-CoV-2 who received remdesivir detected $10 \%$ of the dose to be excreted in urine. However, in these same volunteers, $49 \%$ of GS-441524, remdesivir's prodrug, was detected in the urine (2). GS-441524 has also been observed to be elevated in both patients with mild renal dysfunction and patients requiring intermittent hemodialysis (6-9). However, it has been suggested that GS-704277, a transient prodrug of remdesivir prior to further hydrolysis to GS441524 , is accumulated in renal disease and is, in turn, responsible for the elevated serum concentrations of GS-441524 in the population (10). Regardless, no dose adjustments are recommended for patients with renal dysfunction at this time. Routine monitoring of liver function tests (LFTs) is recommended in patients receiving remdesivir, with guidance to discontinue the drug in patients with alanine aminotransferase (ALT) of $\geq 10$ times the upper limit of normal (ULN) (2). Therefore, it is unclear if the potential accumulation of either GS-441524 or GS-704277 in patients with renal disease receiving remdesivir would increase the risk of adverse effects.

Given the limited solubility of remdesivir, sulfobutylether-beta-cyclodextrin sodium (SBECD) is required for intravenous (i.v.) administration (11). Although nephrotoxicity has been associated with the administration of first-generation $\beta$-cyclodextrins by way of accumulation into renal epithelial cells, SBECD has been designed not to accumulate in renal epithelial cells (12). Despite this, i.v. remdesivir was shown to be nephrotoxic at doses of $5 \mathrm{mg} / \mathrm{kg} /$ day for 7 days in rhesus monkeys and at doses of $\geq 3 \mathrm{mg} / \mathrm{kg} /$ day for up to 4 weeks in rats (2). However, these respective doses are 3.5-fold and 2.1-fold higher than the daily doses used for the treatment of SARS-CoV-2 infections in humans (2). It is encouraging that in clinical practice, a total of four cases of acute kidney injury (AKI) in patients receiving remdesivir have been reported to a national French pharmacovigilance database, and no cases were considered causal (13). Occurrence of AKI in patients with SARS-CoV-2 who received remdesivir in clinical trials has also been observed, albeit at low rates comparable to placebo $(3,5,14)$.

Regardless, in the absence of definitive clinical data, prescribing guidance recommends against use of remdesivir in patients with an estimated glomerular filtration rate (eGFR) of $<30 \mathrm{ml} / \mathrm{min}$ unless the benefit outweighs the risk (2). Although eGFR has traditionally been calculated using the modification of diet in renal disease equation, remdesivir's original fact sheet for health care providers under the Emergency Use Authorization (EUA) recommended using the Cockcroft-Gault equation (15). Guidance from the European Medicines Agency is even more restrictive and currently states that remdesivir is contraindicated in severe renal impairment (16).

Given that AKI has been reported to occur in over one-fourth of hospitalized patients with SARS-CoV-2, there is an unmet clinical need to identify if remdesivir therapy is safe in patients with an estimated creatinine clearance $(\mathrm{eCrCl})$ of $<30 \mathrm{ml} /$ $\min$ (17). Often, the benefit of remdesivir outweighs the theoretical risk of SBECD and GS-441524 accumulation considering the high mortality rate associated with hospitalization due to SARS-CoV-2. Therefore, the purpose of this study was to compare the risk of safety outcomes between hospitalized SARS-CoV-2 patients with an $\mathrm{eCrCl}$ of $<30 \mathrm{ml} / \mathrm{min}$ and an $\mathrm{eCrCl}$ of $\geq 30 \mathrm{ml} / \mathrm{min}$ who required remdesivir administration. 


\section{RESULTS}

Of 359 patients who received remdesivir, 347 met inclusion criteria. Twelve patients were excluded because they required renal replacement therapy prior to remdesivir initiation. Of the patients who met inclusion criteria, there were 40 patients with an $\mathrm{eCrCl}$ of $<30 \mathrm{ml} / \mathrm{min}$ and 307 patients with an $\mathrm{eCrCl}$ of $\geq 30 \mathrm{ml} / \mathrm{min}$.

Patients with an eCrCl of $<30 \mathrm{ml} / \mathrm{min}$ were older (median, 80 years [interquartile range [IQR], 63.8 to 89$]$ versus 62 [IQR, 54 to 74$] ; P<0.001$ ), were more likely to be on vasopressors on the day of remdesivir initiation ( $30 \%$ versus $12.7 \%$; $P=0.003)$, and were more likely to be mechanically ventilated on the day of remdesivir initiation $(27.5 \%$ versus 12.4\%; $P=0.01$ ) than those with an $\mathrm{eCrCl}$ of $\geq 30 \mathrm{ml} / \mathrm{min}$ (Table 1). Despite these confounders, there was no significant difference in the frequency of end-of-treatment (EOT) AKI ( $5 \%$ versus $2.3 \% ; P=0.283$ ) or early discontinuation due to abnormal LFTs ( $0 \%$ versus $3.9 \% ; P=0.374)$. However, patients with an $\mathrm{eCrCl}$ of $<30 \mathrm{ml} / \mathrm{min}$ calculated on the first day of administration of remdesivir had a higher 30-day mortality rate than those with an $\mathrm{eCrCl}$ of $\geq 30 \mathrm{ml} / \mathrm{min}$ (50\% versus $16.2 \% ; P<0.001$ ). Of the two patients who developed EOT AKI on remdesivir with an $\mathrm{eCrCl}<30 \mathrm{ml} / \mathrm{min}$, no cases were attributable to remdesivir administration per the treating physician. One patient was deemed to have developed AKI due to hypotension, and the other patient's nephrologist deemed AKI to be secondary to either tacrolimus toxicity or contrast-induced nephropathy.

A subset analysis of patients without AKI on the day of remdesivir initiation did not identify an $\mathrm{eCrCl}$ of $<30 \mathrm{ml} / \mathrm{min}$ to be associated with either EOT AKI (4.2\% versus $2 \%$; $P=0.425$ ) or early discontinuation due to abnormal LFTs ( $0 \%$ versus $4 \% ; P>0.999$ ); however, patients within this subset with an $\mathrm{eCrCl}$ of $<30 \mathrm{ml} / \mathrm{min}$ also had a higher 30-day mortality rate than those with an $\mathrm{eCrCl}$ of $\geq 30 \mathrm{ml} / \mathrm{min}$ (55\% versus $16.5 \%$; $P<0.001$ ) (Table 2).

When nearest neighbor matching was applied, there was no significant difference in age (median, 80 years [IQR, 63.8 to 89 ] versus 84 [IQR, 70.8 to 87.5$]$ ]; $P=0.554$ ), use of vasopressors on the day of remdesivir initiation (30\% versus $20 \% ; P=0.302)$, or use of mechanical ventilation on the day of remdesivir initiation $(27.5 \%$ versus $20 \% ; P=0.431)$ in patients with an $\mathrm{eCrCl}$ of $<30 \mathrm{ml} / \mathrm{min}$ compared to those with an $\mathrm{eCrCl}$ of $\geq 30 \mathrm{ml} /$ min (Table 3). However, baseline presence of heart failure, diabetes mellitus, and AKI on the day of remdesivir initiation remained significantly more common in patients with an eCrCl of $<30 \mathrm{ml} / \mathrm{min}$. Regardless, there was no significant difference in the frequency of EOT AKI ( $5 \%$ versus $2.5 \% ; P>0.999$ ) or early discontinuation due to abnormal LFTs $(0 \%$ versus $5 \% ; P=0.494)$.

\section{DISCUSSION}

To our knowledge, this is the first study to evaluate the risk of nephrotoxicity of remdesivir in patients with an $\mathrm{eCrCl}$ of $<30 \mathrm{ml} / \mathrm{min}$. All randomized trials published to date which have evaluated the use of remdesivir in patients with SARS-CoV-2 have excluded patients with renal disease $(3,5,14)$. Therefore, in addition to our evaluation of the risk of AKI in patients who receive remdesivir, our analysis also revealed no increased risk of LFT abnormalities in patients with SARS-CoV-2 who receive remdesivir in the setting of renal disease.

There was a relatively low frequency of EOT AKI in our cohort, which is consistent with previously reported literature. In clinical trials, the frequency of AKI among hospitalized patients treated with remdesivir for SARS-CoV-2 has ranged from $1 \%$ to $4.7 \%$ (3, $5,14)$. In addition, these same clinical trials report the frequency of ALT elevations attributable to remdesivir to have occurred in $1 \%$ to $6.5 \%$ of patients, which is also consistent with our findings $(3,5,14)$.

The administration of remdesivir for SARS-CoV-2 has been advocated without regard to eCrCl, as many clinicians have extrapolated safety data from i.v. voriconazole, which is formulated with SBECD (7). Each 100-mg dose of lyophilized remdesivir powder is formulated with $3 \mathrm{~g}$ of SBECD, which is comparable to a standard formulation of $200 \mathrm{mg}$ of i.v. voriconazole, which contains $3.2 \mathrm{~g}$ of $\operatorname{SBECD}(2,19)$. Therefore, it is 
TABLE 1 Full bivariate analysis

\begin{tabular}{|c|c|c|c|}
\hline \multirow[b]{2}{*}{ Characteristic $^{d}$} & \multicolumn{2}{|c|}{ Patients with an eCrCL of: } & \multirow[b]{2}{*}{$P$ value $^{e}$} \\
\hline & $<30 \mathrm{ml} / \mathrm{min}(n=40)$ & $\geq 30 \mathrm{ml} / \mathrm{min}(n=307)$ & \\
\hline \multicolumn{4}{|l|}{ Baseline demographics and treatment information } \\
\hline Age (median [IQR] [yrs]) & $80(63.8-89)$ & $62(54-74)$ & $<0.001^{a}$ \\
\hline Female gender (no. [\%]) & $23(57.5)$ & $146(47.6)$ & $0.237^{b}$ \\
\hline Body mass index of $>30 \mathrm{~kg} / \mathrm{m}^{2}$ (no. [\%]) & $14(35)$ & $149(48.5)$ & $0.117^{b}$ \\
\hline Cirrhosis (no. [\%]) & $2(5)$ & $4(1.3)$ & $0.114^{c}$ \\
\hline Diabetes mellitus (no. [\%]) & $24(60)$ & 95 (30.9) & $<0.001^{b}$ \\
\hline Heart failure (no. [\%]) & $18(45)$ & $33(10.7)$ & $<0.001^{b}$ \\
\hline Hypertension (no. [\%]) & $34(85)$ & $176(57.3)$ & $<0.001^{b}$ \\
\hline Renal transplant (no. [\%]) & $1(2.5)$ & $3(1)$ & $0.389^{c}$ \\
\hline Baseline SCr (median [IQR] [mg/dl]) & $1.2(1-2.1)$ & $0.85(0.7-1)$ & $<0.001^{a}$ \\
\hline $\mathrm{SCr}$ on the day of remdesivir administration (median $[\mathrm{IQR}][\mathrm{mg} / \mathrm{dl}]$ ) & $2.8(1.6-4.2)$ & $0.87(0.7-1.1)$ & $<0.001^{a}$ \\
\hline $\mathrm{CrCl}(\mathrm{ml} / \mathrm{min})$ on the day of remdesivir administration by $\mathrm{C}-\mathrm{G}$ (median [IQR]) & $20.3(15.3-26.3)$ & $82.5(57.8-108.6)$ & $<0.001^{a}$ \\
\hline eGFR $\left(\mathrm{ml} / \mathrm{min} / 1.73 \mathrm{~m}^{2}\right)$ on the day of remdesivir administration by MDRD (median [IQR]) & $21(15.2-34.1)$ & $89.4(63.8-111.7)$ & $<0.001^{a}$ \\
\hline ALT $>5 \times$ ULN on the first day of remdesivir administration & & & $0.638^{c}$ \\
\hline Total no. & 40 & 304 & \\
\hline No. (\%) & $2(5)$ & $10(3.3)$ & \\
\hline In AKI on the day of remdesivir administration (no. [\%]) & $16(40)$ & $8(2.6)$ & $<0.001^{b}$ \\
\hline Vasopressor or inotrope use during remdesivir (no. [\%]) & $12(30)$ & $39(12.7)$ & $0.003^{b}$ \\
\hline Mechanical ventilation during remdesivir (no. [\%]) & $11(27.5)$ & $38(12.4)$ & $0.01^{b}$ \\
\hline \multicolumn{4}{|l|}{ Concomitant nephrotoxic drug (no. [\%]) } \\
\hline Vancomycin & $5(12.5)$ & $52(16.9)$ & $0.65^{c}$ \\
\hline Aminoglycoside & $1(2.5)$ & $0(0)$ & $0.115^{c}$ \\
\hline i.v. acyclovir & $1(2.5)$ & $0(0)$ & $0.115^{c}$ \\
\hline TMP-SMX & $0(0)$ & $4(1.3)$ & $>0.999^{c}$ \\
\hline Amphotericin B & $0(0)$ & $0(0)$ & $>0.999^{c}$ \\
\hline $\mathrm{ACE} / \mathrm{ARB}$ & $8(20)$ & $50(16.3)$ & $0.554^{b}$ \\
\hline Loop/thiazide diuretics & $24(60)$ & $106(34.5)$ & $0.002^{b}$ \\
\hline Tacrolimus/cyclosporine & $1(2.5)$ & $3(1)$ & $0.389^{c}$ \\
\hline i.v. contrast & $3(7.5)$ & $41(13.4)$ & $0.447^{c}$ \\
\hline NSAIDS & $0(0)$ & $7(2.3)$ & $>0.999^{c}$ \\
\hline Days of remdesivir treatment (median [IQR]) & $5(4-5)$ & $5(5-5)$ & $0.002^{a}$ \\
\hline \multicolumn{4}{|l|}{ Safety outcomes } \\
\hline AKI using EOT SCr & & & $0.283^{c}$ \\
\hline Total no. & 40 & 303 & \\
\hline No. $(\%)$ & $2(5)$ & $7(2.3)$ & \\
\hline AKI using peak SCr (no. [\%]) & $2(5)$ & $11(3.6)$ & $0.652^{c}$ \\
\hline AKI $48 \mathrm{~h}$ posttreatment & & & $0.212^{c}$ \\
\hline Total no. & 21 & 173 & \\
\hline No. $(\%)$ & $3(14.3)$ & $12(6.9)$ & \\
\hline ALT $>5 \times$ ULN on last day of remdesivir & & & $0.145^{c}$ \\
\hline Total no. & 38 & 294 & \\
\hline No. $(\%)$ & $0(0)$ & $19(6.5)$ & \\
\hline Remdesivir discontinued early due to abnormal LFTs (no. [\%]) & $0(0)$ & $12(3.9)$ & $0.374^{c}$ \\
\hline 30-day mortality & & & $<0.001^{b}$ \\
\hline Total no. & 34 & 232 & \\
\hline No. (\%) & 19 (55.9) & 38 (16.4) & \\
\hline
\end{tabular}

aMann-Whitney U test.

${ }^{b}$ Chi-square test.

cFisher's exact test.

${ }^{d} \mathrm{C}-\mathrm{G}$, Cockgrauft-Gault equation; MDRD, modification of diet in renal disease; TMP-SMX, trimethoprim-sulfamethoxazole; ACE/ARB, angiotensin-converting enzyme/ angiotensin receptor blocker; NSAIDS, nonsteroidal anti-inflammatory drugs; SCr, serum creatinine; LFTs, liver function tests.

eBolded values are $P<0.05$.

reassuring that the majority of studies evaluating i.v. voriconazole in patients with underlying renal disease have found no risk of nephrotoxicity $(20,21)$.

The only study which identified possible nephrotoxicity associated with i.v. voriconazole used a cumulative dose of $\geq 400 \mathrm{mg} / \mathrm{kg}$ (22). Achieving this cumulative dose would require at least 50 days of voriconazole therapy assuming a standard maintenance dose of $4 \mathrm{mg} / \mathrm{kg}$ every $12 \mathrm{~h}$. Only two patients in our cohort received 10 days of remdesivir therapy, and we 
TABLE 2 Subgroup analysis of patients without AKI on the day of remdesivir administration

\begin{tabular}{|c|c|c|c|}
\hline \multirow[b]{2}{*}{ Characteristic $^{d}$} & \multicolumn{2}{|c|}{ Patients with an eCrCL of: } & \multirow[b]{2}{*}{$P$ value ${ }^{e}$} \\
\hline & $\begin{array}{l}<30 \mathrm{ml} / \mathrm{min} \\
(n=24)\end{array}$ & $\begin{array}{l}\geq 30 \mathrm{ml} / \mathrm{min} \\
(n=299)\end{array}$ & \\
\hline AKI using EOT SCr & & & $0.425^{c}$ \\
\hline Total no. & 24 & 295 & \\
\hline No. (\%) & $1(4.2)$ & $6(2)$ & \\
\hline $\mathrm{AKI}$ using peak $\mathrm{SCr}$ & & & $0.578^{c}$ \\
\hline Total no. & 24 & 299 & \\
\hline No. (\%) & $1(4.2)$ & $10(3.3)$ & \\
\hline ALT $>5 \times$ ULN on last day of remdesivir & & & $0.378^{a}$ \\
\hline Total no. & 24 & 286 & \\
\hline No. (\%) & $0(0)$ & $18(6.3)$ & \\
\hline $\begin{array}{l}\text { Remdesivir discontinued early due to } \\
\text { abnormal LFTs (no. [\%]) }\end{array}$ & $0(0)$ & $12(4)$ & $>0.999^{c}$ \\
\hline 30-day mortality & & & $<0.001^{b}$ \\
\hline Total no. & 20 & 224 & \\
\hline No. (\%) & $11(55)$ & $37(16.5)$ & \\
\hline
\end{tabular}

${ }^{a}$ Mann-Whitney U test.

${ }^{b}$ Chi-square test.

cFisher's exact test.

${ }^{d} \mathrm{SCr}$, serum creatinine; LFTs, liver function tests.

${ }^{e}$ Bolded values are $P<0.05$.

suspect the majority of patients would routinely receive a 5-day course in light of a randomized controlled trial which failed to show a significant benefit between a 5-day course versus a 10-day course of remdesivir in patients with severe SARS-CoV-2 (14).

However, the potential from renal toxicity from the accumulation of remdesivir's active metabolites remains to be fully elucidated. An anecdotal report of a double lung transplant patient with normal renal function at baseline who received remdesivir for the treatment of SARS-CoV-2 experienced renal failure 3 days after the drug was initiated (18). The patient demonstrated elevated serum levels of GS-441524 despite undetectable remdesivir concentrations while in renal failure, which suggests that while remdesivir itself may not be nephrotoxic, GS-441524 accumulation may be responsible for renal injury. Ultimately, the patient's clinicians deemed the cause of acute kidney injury to be multifactorial (13).

Studies in mice have demonstrated that GS-441524 does not cause nephrotoxicity, but GS-704277, a transient prodrug of remdesivir prior to further hydrolysis to GS441524 , does. On the other hand, the mechanism of renal toxicity of GS-704277 in mice is mediated through organic ion transporters (OAT), and active transport of GS704277 has never been detected in humans (13).

Although this study did not identify a significantly increased risk of AKI or LFT abnormalities in patients who received remdesivir with an $\mathrm{eCrCl}$ of $<30 \mathrm{ml} / \mathrm{min}$, there was a significantly higher mortality rate in this population. We suspect that the higher mortality rate in patients with an $\mathrm{eCrCl}$ of $<30 \mathrm{ml} / \mathrm{min}$ is attributable to the older age, more comorbidities, more frequent use of vasopressors or inotropes, and more frequent use of mechanical ventilation. However, it is noteworthy that a cohort of over 17 million patients has identified renal disease to be a predictor of SARS-CoV-2-related mortality (23). It should also be recognized that over one-fourth of patients with an $\mathrm{eCrCl}$ of $<30 \mathrm{ml} / \mathrm{min}$ required mechanical ventilation, and to date, there is no evidence of efficacy of remdesivir for SARSCoV-2 in this patient population. Although the aim of our report was not to assess the efficacy of remdesivir, it is noteworthy that in a randomized controlled trial of hospitalized patients due to SARS-CoV-2, the administration of remdesivir failed to impact the time to recover compared to placebo in a subset of 285 patients receiving mechanical ventilation or extracorporeal membrane oxygenation (3). The overall efficacy of the drug continues to undergo scrutiny, given the unpublished interim results of the SOLIDARITY trial suggest 
TABLE 3 Matched bivariate analysis

\begin{tabular}{|c|c|c|c|}
\hline \multirow[b]{2}{*}{ Characteristic $^{d}$} & \multicolumn{2}{|c|}{ Patients with an eCrCL of: } & \multirow[b]{2}{*}{$P$ value } \\
\hline & $<30 \mathrm{ml} / \mathrm{min}(n=40)$ & $\geq 30 \mathrm{ml} / \mathrm{min}(n=40)$ & \\
\hline \multicolumn{4}{|l|}{ Baseline demographics and treatment information } \\
\hline Age (median [IQR] [yrs]) & $80(63.8-89)$ & $84(70.8-87.5)$ & $0.554^{a}$ \\
\hline Female gender (no. [\%]) & $23(57.5)$ & $18(45)$ & $0.263^{b}$ \\
\hline Body mass index of $>30 \mathrm{~kg} / \mathrm{m}^{2}$ (no. [\%]) & $14(35)$ & $16(40)$ & $0.644^{b}$ \\
\hline Cirrhosis (no. [\%]) & $2(5)$ & $0(0)$ & $0.494^{c}$ \\
\hline Diabetes mellitus (no. [\%]) & $24(60)$ & $12(30)$ & $0.007^{b}$ \\
\hline Renal transplant (no. [\%]) & $1(2.5)$ & $0(0)$ & $>0.999^{c}$ \\
\hline Baseline SCr (median [IQR] [mg/dl]) & $1.2(1-2.1)$ & $0.85(0.7-1)$ & $<0.001^{a}$ \\
\hline $\mathrm{SCr}(\mathrm{mg} / \mathrm{dl})$ on the day of remdesivir administration (median [IQR]) & $2.8(1.6-4.2)$ & $0.9(0.8-1.3)$ & $<0.001^{a}$ \\
\hline $\mathrm{CrCl}(\mathrm{ml} / \mathrm{min})$ on the day of remdesivir administration by C-G (median [IQR]) & $20.3(15.3-26.3)$ & $51.3(38.3-66.6)$ & $<0.001^{a}$ \\
\hline eGFR $\left(\mathrm{ml} / \mathrm{min} / 1.73 \mathrm{~m}^{2}\right)$ on the day of remdesivir administration by MDRD (median [IQR]) & $21(15.2-34.1)$ & $73.6(53.8-93.9)$ & $<0.001^{a}$ \\
\hline Mechanical ventilation during remdesivir (no. [\%]) & $11(27.5)$ & $8(20)$ & $0.431^{b}$ \\
\hline \multicolumn{4}{|l|}{ Concomitant nephrotoxic drug (no. [\%]) } \\
\hline Vancomycin & $5(12.5)$ & $9(22.5)$ & $0.239^{c}$ \\
\hline Aminoglycoside & $1(2.5)$ & $0(0)$ & $>0.999^{c}$ \\
\hline i.v. acyclovir & $1(2.5)$ & $0(0)$ & $>0.999^{c}$ \\
\hline TMP-SMX & $0(0)$ & $0(0)$ & $>0.999^{c}$ \\
\hline Amphotericin B & $0(0)$ & $0(0)$ & $>0.999^{c}$ \\
\hline ACE/ARB & $8(20)$ & $8(20)$ & $>0.999^{c}$ \\
\hline Loop/thiazide diuretics & $24(60)$ & $15(37.5)$ & $0.04^{b}$ \\
\hline Tacrolimus/cyclosporine & $1(2.5)$ & $0(0)$ & $>0.999^{c}$ \\
\hline i.v. contrast & $3(7.5)$ & $7(17.5)$ & $0.311^{c}$ \\
\hline NSAIDS & $0(0)$ & $1(2.5)$ & $>0.999^{c}$ \\
\hline \multicolumn{4}{|l|}{ Safety outcomes } \\
\hline Remdesivir discontinued early due to abnormal LFTs (no. [\%]) & $0(0)$ & $2(5)$ & $0.494^{c}$ \\
\hline 30-day mortality & & & $0.029^{b}$ \\
\hline Total no. & 34 & 31 & \\
\hline No. (\%) & $19(55.9)$ & $9(29)$ & \\
\hline
\end{tabular}

aMann-Whitney U test.

${ }^{b}$ Chi-square test.

'Fisher's exact test.

${ }^{d} \mathrm{C}-\mathrm{G}$, Cockgrauft-Gault equation; MDRD, modification of diet in renal disease; TMP-SMX, trimethoprim-sulfamethoxazole; ACE/ARB, angiotensin-converting enzyme/ angiotensin receptor blocker; NSAIDS, nonsteroidal anti-inflammatory drugs; SCr, serum creatinine; LFTs, liver function tests.

${ }^{e}$ Bolded values are $P<0.05$

remdesivir does not prevent mortality or initiation of ventilation or reduce the duration of hospital stay in patients with SARS-CoV-2 (24).

The strengths of this study include its multicenter, real-world use, and its novelty. Within our health system, we have encountered clinicians who have not administered remdesivir for patients with symptomatic SARS-CoV-2 due to the risk of both SBECD and GS-441524 accumulation, which emphasizes the need for the presented data. However, several limitations also exist with this study. First, given the observational nature of the study, there are baseline confounders despite an attempt to balance groups through nearest neighbor matching, which may have been attributable to the small sample size of these variables in the full cohort. However, nearly all of these baseline confounders were captured to evaluate the risk of AKI, and, while these risk factors 
were significantly more common in patients with an $\mathrm{eCrCl}$ of $<30 \mathrm{ml} / \mathrm{min}$, there was no significant association with endpoints evaluating renal toxicity. Second, this analysis is limited by the small number of patients with an $\mathrm{eCrCl}$ of $<30 \mathrm{ml} / \mathrm{min}$. Despite the fact that this was a multicenter study in five institutions, we were only able to include 40 patients with an $\mathrm{eCrCl}$ of $<30 \mathrm{ml} / \mathrm{min}$. Therefore, evaluation of remdesivir in a larger cohort of patients with renal disease may be difficult given many clinicians may be hesitant to administer the drug in this population. Nevertheless, further safety evaluation of remdesivir in patients with an $\mathrm{eCrCl}$ of $<30 \mathrm{ml} / \mathrm{min}$ is warranted. Third, it is noteworthy that all patients in this study received remdesivir as a lyophilized powder, which contains less SBECD than remdesivir as an injectable solution ( $3 \mathrm{~g}$ versus $6 \mathrm{~g}$ ); therefore, caution is warranted when extrapolating the results from the study (2). Finally, therapeutic drug monitoring of neither remdesivir, GS-441524, GS-704277, nor SBECD was performed given that these assays are not commercially available. While it is noteworthy that plasma concentrations of GS-441524 can be elevated in patients with acute kidney injury, our data would argue against any nephrotoxic consequences or LFT abnormalities from this metabolite (6).

In conclusion, remdesivir administration was not significantly associated with increased EOT AKI in patients with an $\mathrm{eCrCl}$ of $<30 \mathrm{ml} / \mathrm{min}$ compared to patients with an $\mathrm{eCrCl}$ of $\geq 30 \mathrm{ml} / \mathrm{min}$. Based on our findings, remdesivir could be considered therapy for severe infections due to SARS-CoV-2 in this patient population. However, further study is warranted.

\section{MATERIALS AND METHODS}

This study was a multicenter, retrospective chart review of adult patients with SARS-CoV-2 admitted to one of five hospitals within the Yale New Haven Health System who received remdesivir lyophilized powder between 11 May 2020 and 18 October 2020. This study was deemed exempt by the institutional review board given that criteria were met as a quality improvement study. Patients were excluded if they were on renal replacement therapy prior to remdesivir administration. Patients who met inclusion criteria had an $\mathrm{eCrCl}$ that was calculated using the Cockcroft-Gault formula at the time of remdesivir administration given the prescribing guidance under the FDA's Emergency Use Authorization (25). Baseline serum creatinine $(\mathrm{SCr})$ was defined using the most recent $\mathrm{SCr}$ available prior to hospitalization prior to SARS-CoV-2. Patients with an SCr on the day of remdesivir administration that was 1.5 times the baseline $\mathrm{SCr}$ were considered to be in $\mathrm{AKI}$ at the time of remdesivir administration (26).

Safety outcomes were compared between patients with an eCrCl of $<30 \mathrm{ml} / \mathrm{min}$ and an eCrCl of $\geq 30 \mathrm{ml} / \mathrm{min}$ on the day of remdesivir administration. The primary endpoint was AKI at the EOT, defined as an $\mathrm{SCr}$ on the final day of remdesivir administration greater than 1.5 times the $\mathrm{SCr}$ used on the first day of remdesivir. Secondary endpoints included AKI defined by peak $\mathrm{SCr}$ during remdesivir therapy, AKI 48 hours after completion of remdesivir, discontinuation of remdesivir due to abnormal LFTs, ALT of $\geq 5$ times the ULN on the last day of remdesivir, and all-cause 30-day mortality. ALT normal values were in concordance with recommendations from the American College of Gastroenterology (27). Patients with an ALT of $\geq 5$ times the ULN on the first day of remdesivir administration or who did not have an ALT obtained on the last day of remdesivir administration were excluded from the secondary endpoint evaluating the frequency of ALT of $\geq 5$ times the ULN on the last day of remdesivir. Patients without an available outcome at 30 days were excluded from the secondary endpoint evaluating 30-day mortality. A subset analysis was performed for patients without AKI at the time of remdesivir initiation.

Categorical variables were compared by a chi-square test or Fisher's exact test. Fisher's exact test was performed on samples with an expected frequency of less than or equal to 5, while the chisquare test was performed on samples with an expected frequency of greater than 5 . Continuous variables were compared using a Mann-Whitney $\mathrm{U}$ test. Categorical and continuous variables were deemed statistically significant if they possessed a $P$ value of $<0.05$. Matching was performed using a 1:1 nearest neighbor method by the following factors: age, mechanical ventilation during remdesivir, vasopressor or inotrope use during remdesivir, days of remdesivir treatment, AKI on the day of remdesivir treatment, diabetes mellitus, and heart failure. Statistical analyses were performed with the software $\mathrm{R}$ with the installed Commander and Matchit packages (28).

\section{ACKNOWLEDGMENTS}

S.S. contributed to the conception of the research; T.W.A. contributed to the acquisition of data; all authors contributed to the design of the research; B.C. and S.S. contributed to the analysis of data; T.W.A., S.S., D.M., and J.E.T. contributed to the interpretation of data; and T.W.A. and S.S. drafted the manuscript. All authors critically revised the manuscript, agree to be fully accountable for ensuring the integrity and accuracy of the work, and read and approved the final manuscript. 
This study was carried out as part of our routine work.

We have no conflicts of interest to declare.

\section{REFERENCES}

1. Chen N, Zhou M, Dong X, Qu J, Gong F, Han Y, Qiu Y, Wang J, Liu Y, Wei Y, Xia J, Yu T, Zhang X, Zhang L. 2020. Epidemiological and clinical characteristics of 99 cases of 2019 novel coronavirus pneumonia in Wuhan, China: a descriptive study. Lancet 395:507-513. https://doi.org/10.1016/ S0140-6736(20)30211-7.

2. Gilead. 2020. Remdesivir (Veklury) package insert. Gilead, Foster City, CA.

3. Beigel JH, Tomashek KM, Dodd LE, Mehta AK, Zingman BS, Kalil AC, Hohmann E, Chu HY, Luetkemeyer A, Kline S, Lopez de Castilla D, Finberg RW, Dierberg K, Tapson V, Hsieh L, Patterson TF, Paredes R, Sweeney DA, Short WR, Touloumi G, Lye DC, Ohmagari N, Oh MD, Ruiz-Palacios GM, Benfield T, Fätkenheuer G, Kortepeter MG, Atmar RL, Creech CB, Lundgren J, Babiker AG, Pett S, Neaton JD, Burgess TH, Bonnett T, Green M, Makowski M, Osinusi A, Nayak S, Lane HC. 2020. Remdesivir for the treatment of Covid-19 - final report. N Engl J Med 383:1813-1826. https://doi.org/10.1056/NEJMoa2007764.

4. Olender SA, Perez KK, Go AS, Balani B, Price-Haywood EG, Shah NS, Wang S, Walunas TL, Swaminathan S, Slim J, Chin B, De Wit S, Ali SM, Soriano Viladomiu A, Robinson P, Gottlieb RL, Tsang TYO, Lee IH, Haubrich RH, Chokkalingam AP, Lin L, Zhong L, Bekele BN, Mera-Giler R, Gallant J, Smith LE, Osinusi AO, Brainard DM, Hu H, Phulpin C, Edgar $\mathrm{H}$, Diaz-Cuervo $\mathrm{H}$, Bernardino JI, GS-US-540-5773 and GS-US-540-5807 Investigators. 2020. Remdesivir for severe coronavirus disease 2019 (COVID-19) versus a cohort receiving standard of care. Clinical Infectious Diseases ciaa1041. https://doi.org/10.1093/cid/ciaa1041.

5. Wang Y, Zhang D, Du G, Du R, Zhao J, Jin Y, Fu S, Gao L, Cheng Z, Lu Q, Hu Y, Luo G, Wang K, Lu Y, Li H, Wang S, Ruan S, Yang C, Mei C, Wang Y, Ding D, Wu F, Tang X, Ye X, Ye Y, Liu B, Yang J, Yin W, Wang A, Fan G, Zhou F, Liu Z, Gu X, Xu J, Shang L, Zhang Y, Cao L, Guo T, Wan Y, Qin H, Jiang Y, Jaki T, Hayden FG, Horby PW, Cao B, Wang C. 2020. Remdesivir in adults with severe COVID-19: a randomised, double-blind, placebo-controlled, multicentre trial. Lancet 395:1569-1578. https://doi.org/10.1016/S0140-6736(20)31022-9.

6. Tempestilli M, Caputi P, Avataneo V, Notari S, Forini O, Scorzolini L, Marchioni L, Ascoli Bartoli T, Castilletti C, Lalle E, Capobianchi MR, Nicastri E, D'Avolio A, Ippolito G, Agrati C, Abbonizio MA, Agrati C, Albarello F, Amadei G, Amendola A, Antinori A, Antonini M, Barbaro R, Bartolini B, Benigni M, Bevilacqua N, Bordi L, Bordoni V, Branca M, Campioni P, Capobianchi MR, Caporale C, Caravella I, Carletti F, Casetti R, Castilletti C, Chiappini R, Ciaralli C, Cimini E, Colavita F, Corpolongo A, Cristofaro M, Curiale S, D'Abramo A, Dantimi C, De Angelis A, De Angelis G, Di Lorenzo R, Di Stefano F, D'Offizi G, the COVID 19 INMI Study Group, et al. 2020. Pharmacokinetics of remdesivir and GS-441524 in two critically ill patients who recovered from COVID-19. J Antimicrob Chemother 75:2977-2980. https://doi.org/10.1093/jac/dkaa239.

7. Davis MR, McCreary EK, Pogue JM. 2020. That escalated quickly: remdesivir's place in therapy for COVID-19. Infect Dis Ther 9:525-536. https://doi .org/10.1007/s40121-020-00318-1.

8. Davis MR, Pham CU, Cies JJ. 2020. Remdesivir and GS-441524 plasma concentrations in patients with end-stage renal disease on haemodialysis. J Antimicrob Chemother dkaa472. https://doi.org/10.1093/jac/dkaa472.

9. Sörgel F, Malin J, Hagmann H, Kinzig M, Bilal M, Eichenauer D, ScherfClavel O, Simonis A, El Tabei L, Fuhr U, Rybniker J. 2020. Pharmacokinetics of remdesivir in a COVID-19 patient with end-stage renal disease on intermittent hemodialysis. medRxiv https://www.medrxiv.org/content/10.1101/2020 10.28.20216887v1.full.

10. Yan VC, Muller FL. 2020. Captisol and GS-704277, but not GS-441524, are credible mediators of remdesivir's nephrotoxicity. Antimicrob Agents Chemother 64:e01920-20. https://doi.org/10.1128/AAC.01920-20.

11. Tiwari G, Tiwari R, Rai AK. 2010. Cyclodextrins in delivery systems: applications. J Pharm Bioallied Sci 2:72-79. https://doi.org/10.4103/0975-7406.67003.

12. Frank DW, Gray JE, Weaver RN. 1976. Cyclodextrin nephrosis in the rat. Am J Pathol 83:367-382.

13. Le Beller $C$, Le Hingrat $Q$, Jaquet $P$, Wicky $P-H$, Bunel V, Massias L, Visseaux B, Messika J, Descamps D, Mal H, Timsit J-F, Peytavin G. 2020. Reply to Yan and Muller, "Captisol and GS-704277, but not GS-441524, are credible mediators of remdesivir's nephrotoxicity." Antimicrob Agents Chemother 64:e01937-20. https://doi.org/10.1128/AAC.01937-20.

14. Goldman JD, Lye DCB, Hui DS, Marks KM, Bruno R, Montejano R, Spinner CD, Galli M, Ahn MY, Nahass RG, Chen YS, SenGupta D, Hyland RH, Osinusi AO, Cao H, Blair C, Wei X, Gaggar A, Brainard DM, Towner WJ, Muñoz J, Mullane KM, Marty FM, Tashima KT, Diaz G, Subramanian A. 2020. Remdesivir for 5 or 10 days in patients with severe Covid-19. N Engl J Med 383:1827-1837. https://doi.org/10.1056/NEJMoa2015301.

15. Levey AS, Bosch JP, Lewis JB, Greene T, Rogers N, Roth D. 1999. A more accurate method to estimate glomerular filtration rate from serum creatinine: a new prediction equation. Ann Intern Med 130:461-470. https:// doi.org/10.7326/0003-4819-130-6-199903160-00002.

16. European Medicines Agency. 2020. Annex of prescribing information for remdesivir. European Medicines Agency, Amsterdam, The Netherlands.

17. Batlle D, Soler MJ, Sparks MA, Hiremath S, South AM, Welling PA, Swaminathan S, COVID-19 and ACE2 in Cardiovascular, Lung, and Kidney Working Group. 2020. Acute kidney injury in COVID-19: emerging evidence of a distinct pathophysiology. J Am Soc Nephrol 31:1380-1383. https://doi.org/10.1681/ASN.2020040419.

18. Lê MP, Le Hingrat $Q$, Jaquet $P$, Wicky PH, Bunel V, Massias L, Visseaux B, Messika J, Descamps D, Mal H, Timsit JF, Peytavin G. 2020. Removal of remdesivir's metabolite GS-441524 by hemodialysis in a double lung transplant recipient with COVID-19. Antimicrob Agents Chemother 64: e01521-20. https://doi.org/10.1128/AAC.01521-20.

19. Pfizer. 2020. Voriconazole package insert. Pfizer, New York, NY.

20. Neofytos D, Lombardi LR, Shields RK, Ostrander D, Warren L, Nguyen MH, Thompson CB, Marr KA. 2012. Administration of voriconazole in patients with renal dysfunction. Clin Infect Dis 54:913-921. https://doi.org/10.1093/cid/cir969.

21. Kim SH, Kwon JC, Park C, Han S, Yim DS, Choi JK, Cho SY, Lee HJ, Park SH, Choi SM, Choi JH, Yoo JH, Lee DG, Lee JW. 2016. Therapeutic drug monitoring and safety of intravenous voriconazole formulated with sulfobutylether $\beta$-cyclodextrin in haematological patients with renal impairment. Mycoses 59:644-651. https://doi.org/10.1111/myc.12517.

22. Yasu T, Konuma T, Kuroda S, Takahashi S, Tojo A. 2018. Effect of cumulative intravenous voriconazole dose on renal function in hematological patients. Antimicrob Agents Chemother 62:e00507-18. https://doi.org/10 .1128/AAC.00507-18.

23. Williamson EJ, Walker AJ, Bhaskaran K, Bacon S, Bates C, Morton CE, Curtis HJ, Mehrkar A, Evans D, Inglesby P, Cockburn J, McDonald HI, MacKenna B, Tomlinson L, Douglas IJ, Rentsch CT, Mathur R, Wong AYS, Grieve R, Harrison D, Forbes H, Schultze A, Croker R, Parry J, Hester F, Harper S, Perera R, Evans SJW, Smeeth L, Goldacre B. 2020. Factors associated with COVID-19-related death using OpenSAFELY. Nature 584:430-436. https://doi.org/10.1038/ s41586-020-2521-4.

24. Pan $H$, Peto $R$, Abdool Karim Q, Alejandria M, Henao-Restrepo AM, Hernández García C, Kieny MP, Malekzadeh R, Murthy S, Preziosi MP, Reddy S, Roses Periago M, Sathiyamoorthy V, Røttingen JA, Swaminathan S. 2020. Repurposed antiviral drugs for COVID-19 -interim WHO SOLIDARITY trial results. medRxiv https://www.medrxiv.org/content/10.1101/2020.10.15.20209817v1.

25. Cockcroft DW, Gault MH. 1976. Prediction of creatinine clearance from serum creatinine. Nephron 16:31-41. https://doi.org/10.1159/000180580.

26. Bellomo R, Ronco C, Kellum JA, Mehta RL, Palevsky P, Acute Dialysis Quality Initiative Workgroup. 2004. Acute renal failure - definition, outcome measures, animal models, fluid therapy and information technology needs: the Second International Consensus Conference of the Acute Dialysis Quality Initiative (ADQI) Group. Crit Care 8:R204-R212. https://doi.org/10.1186/cc2872.

27. Kwo PY, Cohen SM, Lim JK. 2017. ACG Clinical Guideline: evaluation of abnormal liver chemistries. Am J Gastroenterol 112:18-35. https://doi .org/10.1038/ajg.2016.517.

28. R Core Team. 2016. R: a language and environment for statistical computing. R Foundation for Statistical Computing, Vienna, Austria. http://www .R-project.org/. 